DOI: $10.47596 /$ SG.V2I2.154

\title{
PERAN EKSKLUSIF ORANG TUA DALAM MEMBENTUK KONSEP DIRI REMAJA KRISTEN
}

Sostenis Nggebu

STT Saint Paul Bandung sostenis.nggebu@gmail.com

Article History
Submitted
May $6^{\text {th }}, 2021$
Revised
Nov $11^{\text {th }}, 2021$
Accepted
Jan $12^{\text {th }}, 2022$

\section{Keyword}

Adolescents; God; Jesus; parents; selfconcept.

Allah; konsep diri; orangtua; remaja; Yesus.
Abstract: The study of this article is directed at shaping the self-concept of Christian youth. The self-concept is so essential to their existence that its fulfillment requires the active role of their parents. According to God's will, the formation of youth self-concept is an exclusive call from God for parents to build youth into the likeness of Jesus Christ. The author uses the literature study method to explain adolescents' healthy selfconcepts to deepen the discussion. Through this study, the authors found an essential fact that adolescents' self-concept is closely related to the coaches of adolescents in a constructive and applicable manner. Parents have the primary responsibility in guiding youth to become accustomed to hearing God's word and obeying the requirements of Jesus Christ for their lives. In managing a harmonious relationship with God, they learn to discover for themselves the dynamics of life by walking in God's word and are able to apply God's truth in their lives. In this aspect, they will grow into the likeness of Jesus Christ and mature in faith as a tangible manifestation of the actualization of a healthy and true self-concept according to the Christian faith.

Abstrak: Kajian artikel ini diarahkan pada pembentukan konsep diri para remaja Kristen. Konsep diri begitu penting bagi eksistensi mereka maka pemenuhannya memerlukan peran aktif orang tua mereka. Pembentukan konsep diri remaja yang sesuai dengan kehendak Allah merupakan panggilan yang eksklusif dari Allah bagi orang tua untuk membina para remaja menjadi milik Yesus Kristus. Untuk mendalami pembahasannya, penulis menggunakan metode studi pustaka dalam menjelaskan konsep diri yang sehat bagi para remaja. Melalui studi tersebut, penulis menemukan fakta penting bahwa dalam konsep diri remaja erat kaitan dengan pembina terhadap para remaja secara konstruktif dan aplikatif. Orang tua memiliki tanggung jawab utama dalam menuntun para remaja agar membiasakan diri dengar-dengaran akan firman Allah dan taat pada tuntutan Yesus Kristus bagi hidup mereka. Dalam menata hubungan yang harmonis dengan Tuhan, mereka belajar menemukan sendiri dinamika hidup dengan berjalan dalam firman Allah dan mampu menerapkan kebenaran Allah itu di dalam hidup mereka. Dalam aspek inila mereka akan bertumbuh menjadi serupa dengan Yesus Kristus dan menjadi dewasa dalam iman sebagai wujud nyata dari aktualisasi dari konsep diri yang sehat dan benar sesuai iman Kristen. 


\section{PENDAHULUAN}

Konsep diri sebagai perangkat penting bagi tiap individu dalam memandang dirinya. Mohamad Hamdi memaparkan konsep diri berkaitan erat dengan cara pandang seseorang terhadap dirinya sendiri meliputi sikap, perasaan, keyakinan dan persepsi. ${ }^{1}$ Nur Saqinah Galugu dan Samsinar mengaitkan hubungan antara konsep diri yang benar akan memengaruhi dinamika hidup anak. ${ }^{2}$ Itu berarti konsep diri sebagai faktor penentu bagi pengenalan dan ekspresi diri remaja. Memiliki konsep diri yang benar dan sehat dapat memupuk kepercayaan dirinya, mampu mengekspresikan diri dan mendeskripsikan diri sendiri serta menyanggupkan mereka menerima diri sendiri apa adanya. Konsep diri yang sehat dapat menunjang para remaja memenuhi harapan atau idealisme mereka. Kharisma Nail Mazaya dan Ratna Supradewi mengatakan kebermaknaan hidup remaja dapat dicapai melalui pemahaman tentang konsep diri yang semestinya. ${ }^{3}$ Jadi remaja yang memiliki konsep diri yang sehat dan benar dapat menumbuhkan kepercayaan terhadap dirinya yang sehat pula.

Akan tetapi untuk mencapai pemenuhan konsep diri di atas, para remaja mendapat tantangan yang tidak mudah, baik secara interen maupun eksteren. Secara faktual muncul juga faktor-faktor yang dapat menghambat perkembangan kepribadian para remaja. Liana Asnita dkk. memaparkan fakta penelitian mereka terhadap remaja bahwa bobot pemahaman konsep diri remaja berkaitan dengan tingkat stres yang dihadapi oleh mereka. Artinya, rendahnya konsep diri remaja meningkatkan tingkat stres mereka, sebaliknya jika mereka memiliki cara pandang yang sehat tentang konsep diri mereka akan menurunkan tingkat stres mereka. ${ }^{4}$ Faktor eksternal yang bersifat positif dan negatif juga dapat memengaruhi kepribadian para remaja melalui relasi dengan teman sebayanya sebagaimana dikatakan oleh D. Dongorang dan F.M. Boiliu. ${ }^{5}$ Tak dapat dielakan bahwa pengaruh eksternal dapat memengaruhi konsep diri para remaja. Anishah Rikayanti dan Muhammad Nur mengatakan bahwa perkembangan kepribadian para remaja sering diiringi dengan terjadinya perubahan yang berdampak secara positif maupun negatif. ${ }^{6}$ Itu berarti para remaja seperti sedang berada di persimpangan

\footnotetext{
${ }^{1}$ Mohamad Hamdi, Teori Kepribadian, Jilid 2 (Bandung: Alfabeta, 2016), 10.

2 Nur Saqinah Galugu and Samsinar, "Academic Self-Concept, Teacher's Supports and Student's Engagement in the School," Jurnal Psikologi Pendidikan dan Konseling: Jurnal Kajian Psikologi Pendidikan dan Bimbingan Konseling 5, no. 2 (2019): 141-145.

${ }^{3}$ Lihat kajian Kharisma Nail Mazya and Ratna Supradewi, "Konsep Diri Dan Kebermaknaan Hidup Pada Remaja Di Panti Asuhan,” Proyeksi; Jurnal Psikologi, Unissula 6, no. 2 (2021): 103-112.

${ }^{4}$ Liana Asnita dkk, "HUBUNGAN TINGKAT STRES DENGAN HARGA DIRI REMAJA DI LEMBAGA PEMASYARAKATAN," Jurnal JOM Program Studi Keperawatan Universitas Riau 2, no. 2 (2015).

5 Darminto Dongoran and Fredik Melkias Boiliu, "Pergaulan Teman Sebaya Dalam Pembentukan Konsep Diri Siswa," Jurnal Educatio FKIP Unma 6, no. 2 (2020): 381-388.

${ }^{6}$ Anisah Rikayanti and Muhammad Nur, "Hubungan Harga Diri Dengan Aktualisasi Diri Pada Remaja Putri Dengan Obisitas Di SMA Negeri 4 Makassar," Jurnal Stikes Nani Hasanuddin 3, no. 6 (2013): 108.
} 
jalan yang dapat menjerumuskan diri mereka ke dalam kesulitan. Mereka tidak bisa berjalan sendiri; mereka butuh bantuan dari orang tua untuk menumbukembangkan konsep diri mereka menjadi dewasa.

Dengan demikian dapat dikatakan bahwa para remaja membutuhkan peran orang tua dalam pemenuhan konsep diri mereka. Sentralitas pembentukan konsep diri remaja ada pada genggaman orang tua. Keterlibatan orang tua dapat membangun kepribadian para remaja agar mereka mampu berkembang secara sehat. Pandangan yang serupa ditegaskan oleh Sri Wening, bahwa religiositas remaja dapat bertumbah secara benar melalui pembinaan iman oleh guru maupun orang tua. ${ }^{7}$ Pembinaan iman bagi para remaja oleh orang tua demi memenuhi religiositas mereka, kedewasaan rohani dan takut akan Tuhan. Mereka menjadi generasi yang beriman yang menaati setiap perkataan Tuhan. Ester Melati mengatakan bahwa terdapat korelasi antara pengaruh pembinaan iman Kristen oleh orang tua terhadap pembentukan moralitas remaja. ${ }^{8}$ Artinya, ketenangan pribadi, kematangan dan penguasaan diri remaja dapat dibentuk oleh orang tua. Mengingat begitu pentingnya pembentukan konsep diri remaja maka dibutuhkan peran serta orang tua untuk menolong para remaja mereka dapat memiliki konsep diri yang sehat dan benar sesuai dengan terang firman Allah.

Untuk maksud itu penulis merumuskan masalah penelitian: bagaimana peran eksklusif orang tua dalam pembentukan konsep diri remaja Kristen? Tujuan dari penelitian ini adalah menjelaskan peran eksklusif orang tua dalam membentuk konsep diri remaja Kristen.

\section{METODE PENELITIAN}

Penelitian ini menggunakan metode studi literatur. Suharsimi Arikunto menegaskan bahwa studi literatur mengacu pada dokumen tertulis. ${ }^{9}$ Metode studi pustaka merupakan serangkaian pendekatan untuk menyelesaikan permasalahan dengan menyelidiki data dari pustaka yang berkaitan dengan problematika konsep diri para remaja Kristen. Penelitian ini diarahkan untuk mengkaji literatur yang aktual berupa buku cetak, buku PDF atau artikel jurnal online, yang membahas tentang problematika konsep diri remaja. Selain itu penulis juga menggunakan software komputer Bible Works 10 versi 10.0.4.114 (Starup 8.88 secs) untuk menganalisis arti kata Yunani yang dikutip dalam tubuh artikel ini. Dari fakta-fakta tersebut, penulis membangun analisis dan kajian terhadap masalah konsep diri remaja Kristen yang dituangkan pembahasan dalam artikel ini.

\footnotetext{
${ }^{7}$ Sri Wening, "Pengaruh Pola Asuh Autoritatif Terhadap Religiositas Remaja Gereja Kristen Jawa Se-Klasis Surakarta," Kurios 4, no. 1 (2018): 74.

${ }^{8}$ Rikayanti and Nur, "Hubungan Harga Diri Dengan Aktualisasi Diri Pada Remaja Putri Dengan Obisitas Di SMA Negeri 4 Makassar."

${ }^{9}$ Suharsimi Arikunto, Prosedur Penelitian (Jakarta: Rineka Cipta, 2013).
} 


\section{HASIL DAN PEMBAHASAN}

\section{Mandat Eksklusif bagi Orang tua dalam Pembinaan Rohani Remaja}

Sebelum muncul institusi formal dalam keagamaan, orang tua memiliki peran yang terutama dalam masalah kerohanian dalam keluarga. Para ayah berperan sebagai iman dalam keluargnya. Tepat sekali Alkitab menguraikan tentang tanggung jawab eksklusif bagi orang tua dalam membina dan membentuk kerohanian anak-anaknya. W.S. Heath mengatakan kehendak Allah menjadi dasar bagi pendidikan dan pembinaan iman yang tertuang jelas dalam kitab Ulangan yang disebut Shema. ${ }^{10}$ Shema berperan sebagai dasar pembinaan iman dalam keluarga Ibrani. Tiap anak dalam keluarga Ibrani dituntut untuk "dengar" ("shama," "hear"). Dalam Bible Works 10 dipaparkan arti kata שֵַָׁ (shama) yakni mendengar firman untuk sepenuhnya ditaati, memerhatikan dengan sungguhsungguh, mendengarkan dengan saksama. Tujuan mendengarkan firman Allah agar anak percaya kepada Allah yang hidup. Itu berarti orang tua Kristen tidak perlu lagi bersusah payah merumuskan teori yang dipakai sebagai dasar untuk membina anak-anak mereka. Firman Allah menjadi sumber utama bagi pembinaan kerohanian anak dan para remaja yang teruang jelas dalam Ulangan 6:4-9 dan Keluaran 20. I. Putu Ayub Darmawan mengatakan orang Yahudi menggunakan setiap kesempatan untuk mendidik anak-anak mereka mengingat perintah Tuhan bagi hidup mereka. ${ }^{11}$ Dalam kitab singkat penutup Perjanjian Lama ditegaskan betapa pentingnya orang tua mendidik anak mereka dalam iman kepada Tuhan (Mal 4:5-6). Bahkan dalam Injil, Yesus membiarkan anak-anak itu datang kepadaNya (Mat 19:4; Mrk 10:14; Luk 18:16). Rasul Paulus juga menegaskan kepada orang tua supaya aktif mendidik anak-anaknya dalam iman (bdk. Ef 6:4). Eirene Mary mengatakan orang tua mendidik anak dalam iman supaya mereka tunduk pada otoritas Allah selain juga mereka tunduk pada orang tau sebagai wakil Allah di bumi. ${ }^{12}$ Secara alkitabiah masalah pembentukan iman anak dan para remaja Kristen seyogianya sudah ditangani secara benar sejak dini melalui tangan dingin orang tua mereka. Maksudnya, konsep diri para remaja sepatutnya sudah tuntas dibentuk agar mereka tahu apa yang mesti diperbuat di dalam kehidupannya di tengah pergaulan masyarakat global.

Orang tua yang lalai menaati firman Allah dalam pembinaan iman anakanaka mereka dicela Tuhan. Iman Eli telah mengabaikan anak-anaknya menyebabkan Tuhan menghukumnya (bdk. 1 Sam 2:27-36; 4:1-22). Yushak Soesilo menguraikan bahwa imam Eli lalai dalam mendisiplinkan anak-anaknya hidup

\footnotetext{
${ }^{10}$ W.S. Heath, Teologi Pendidikan Anak, ed. Yosep Kurnia (Bandung: Kalam Hidup, 2005).

${ }^{11}$ I Putu Ayub Darmawan, "Pembelajaran Memorisasi Dalam Ulangan 6:6-9," EPIGRAPHE: Jurnal Teologi dan Pelayanan Kristiani 3, no. 1 (2019): 21.

12 Eirene Mary, "Implikasi Ulangan 5:16 Dalam Pendidikan Keluarga," Didache: Journal of Christian Education 1, no. 2 (2020): 141.
} 
dalam iman maka mereka menyimpang dari ketetapan Tuhan. ${ }^{13}$ Dengan kata lain kegagalan menyebabkan dirinya bukan tergolong ayah teladan. Kegagalan serupa terjadi pada Raja Salomo yang ternyata lalai terhadap masalah kerohanian anakanaknya maka ia pun ditegur Allah Israel dan kerajaannya dikoyakkan. Yorebeam dan Rahebeam saling bersitegang satu sama lainnya (1 Raj 12-2 Raj 18). Adi Putra mengatakan kegagalan Salomo terletak pada kehidupannya yang menyimpang dari ketetapan Tuhan yakni beristri banyak, mengumpulkan harta dan dosa pemberontakan. ${ }^{14}$ Dampaknya kelalaian dalam mendidik iman anak-anaknya. Begitu juga dengan kebanyakan raja-raja Israel yang tidak menjalankan firman Allah dalam keluarga mereka sehingga menimbulkan kesesatan melanda Israel seperti yang terjadi pada zaman dinasti Omri (2 Raj 16:21-28) dan tampak makin bengis dalam pemerintahan Ahab (2 Raj 16:29-22:-40). Itu terjadi karena orang tua mereka abai terhadap pembinaan iman dan pembentukan konsep diri para remaja mereka. Kosma Manurung telah mengkaji bagian tersebut dan mengatakan bahwa peran nabi palsu telah mencelakakan umat Israel jatuh dalam dosa dan pemberontakan. ${ }^{15}$ Kegagalan itu turut mengganggu pembinaan iman bagi generasi berikutnya.

Sebaliknya Alkitab juga mencatat tentang orang-orang yang setia dalam mendidik anak-anak mereka dalam iman kepada Tuhan seperti Abraham mendidik iman anaknya, Ishak. Teladan yang direkam dari Abraham berbicara lebih kuat sehingga diteruskannya dalam mendidik Yakub menjadi penyembah Yahweh. Selanjutnya, Yakub meneladani dari ayahnya untuk memperlengkapi kedua belas anak menjadi penerus generasi beriman dalam sejarah Israel. Berkenaan dengan tugas mulia itu maka Astrid Maryam Yvonny Nainupu dan Ayang Emiyati memandang bahwa pada prinsipnya orang tua diberi mandat untuk mendidik anak-anak mereka. ${ }^{16}$ Dengan demikian teladan keluarga beriman dalam sejarah keselamatan telah mewariskan bagi orang tua masa kini untuk berperan aktif dalam membina iman anak-anak mereka supaya muncul generasi berikutnya yang memiliki sikap dan perilaku sebagai kaum yang tunduk sepenuh hati kepada Tuhan.

Betapa pentingnya para remaja dibina dalam iman dan konsep diri mereka dibentuk sesuai kehendak Allah agar mereka menjalani hidup mereka sebagaimana mestinya. Gary Thomas menyimpulkan bahwa pembinaan rohani

\footnotetext{
13 Yushak Soesilo, "Keluarga Eli Dalam 1 Samuel 2:11-36: Suatu Evaluasi Pendidikan Kristen Dalam Keluarga Hamba Tuhan,” Jurnal Antusias 3, no. 5 (2014): 136-146.

14 Bandingkan kajian Adi Putra, "Monarki: Penolakan Terhadap Teokrasi," Explore Contact FAQ (2021) tanpa halaman.

15 Kosma Manurung, "Studi Analisis Pandangan Nabi Terhadap Nubuat Palsu," Jurnal Antusias 6, no. 6 (2020): 59-60.

${ }^{16}$ Astrid Maryam Yvonny Nainupu and Ayang Emiyati, "Kunci Keberhasilan Seorang Anak Dalam Pemaparan Alkitab," Didache: Journal of Christian Education 1, no. 2 (2020): 111.
} 
anak merupakan panggilan suci bagi umat Allah. ${ }^{17}$ Tuhan memperlengkapi orang tua dengan kuasa Allah untuk memenangkan anak-anak mereka agar mereka berjalan dalam terang dan kehendak-Nya. ${ }^{18}$ Orang tua Kristen yang mendidik dan membentuk konsep diri para remaja sebagai pelayanan yang terutama dan mulia. Melayani orang lain juga penting tetapi lebih bertanggung jawab apabila mereka sudi membimbing dan mengarahkan buah hati mereka bersandar kepada Tuhan. Karena di situlah taruhannya tentang tanggung jawab pribadi orang tua di hadapan Tuhan.

Remaja Ibrani buangan di negeri Babel, Daniel, ternyata tetap memilih taat kepada Allah dan rela mempertahankan imannya di tengah dunia yang berdosa. ${ }^{19}$ Sikap ini menunjukkan bahwa konsep dirinya telah dibentuk sejak dini dari orang tuanya. Kisah hidup Timotius menjadi sebuah kisah pembelajaran menarik. Bahwa ia juga telah dibentuk konsep dirinya melalui tangan dingin sang bunda, Eunike dan neneknya, Lois (2 Tim 1:5) jauh sebelum ia bertemu dengan rasul Paulus. Kematangan konsep diri membuat Daniel mampu menjaga dirinya dari pengaruh global di negeri pembuangan; demikian juga Timotius mengalami perlindung dari godaan keduniawian dalam lingkungan sosialnya. Keduanya terpelihara dalam iman pada masa hidup mereka. Maka jelas sekali bahwa orang tua yang abai dalam mendidik anak-anak akan menderita kerugian yakni muncul pemberontakan dan penyesatan; sebaliknya orang tua yang memperhatikan kehidupan rohani anakanak akan bersukacita karena buah hati mereka memiliki citra takut akan Tuhan dan bersinar bagi-Nya.

\section{Konsep Diri Remaja dan Dinamikanya}

Konsep diri berarti cara pandang setiap individu terhadap dirinya sendiri. Hensley mengatakan bahwa komponen konsep diri seseorang terdiri dari tiga aspek, yakni meliputi sikap diri terhadap karakteristik pribadi; sikap diri secara fisik terhadap diri sendiri, dan menyangkut kemampunan diri atau motivasi yang dianutnya. ${ }^{20}$ Berdasarkan pandangan Hensley tentang tiga komponen konsep diri yang membentuk kepribadian para remaja mengarahkan pembahasan artikel ini. Pada hakikatnya ketiga komponen tersebut menyatu pada dalam diri seseorang (remaja) dan membentuk sejauhmana kualitas konsep diri yang terinternalisasi di dalam dirinya. Sidjabat kemudian menderetkan penjabarannya bahwa sering remaja bertanya sejauh mana seyogianya penampilnya (berkaitan dengan fisik). Kemudian, mereka juga mempertanyakan sejuah mana prestasi yang dicapainya (secara karakteristik). Terakhir, berkaitan dengan kemampuan bagaimana

\footnotetext{
${ }^{17}$ Gary Thomas, Sacred Parenting, ed. Ellen Hanafi (Yogyakarta: Gloria, 2015).

18 Sostenis Nggebu, Desain Allah Bagi Anak Dan Remaja: Membesarkan Anak Semakin Mendewasakan Orangtua, ed. Heru Winoto (Bandung: Biji Sesawi, 2016).

19 Ibid.

${ }^{20}$ Margaret Hensley, Konsep Diri Dan Kedewasaan Rohani (Bandung: Kalam Hidup, 1993).
} 
pentingnya keberadaan pribadinya. ${ }^{21}$ Tampaknya komponen pembentukan konsep diri begitu penting bagi pengembangan diri remaja. Mulai dari membentuk pemahaman mereka sendiri terhadap masalah konsep diri bagi diri mereka. bahwa konsep diri itu perlu bertumbuh secara sehat dalam pememahaman mereka untuk membentuk sudut pandang yang benar dan sehat. Hal ini menolong mereka bertumbuh menuju pemenuhan darinya menjadi pribadi yang matang, dewasa dan mampu mengatasi persoalan yang muncul dalam dirinya. Komponen itu menjadi daya tahan untuk mengekspresikan diri menjadi pribadi pemenang dalam mencari solusi dalam eksistensinya dalam lingkungan sosialnya. Selain itu, dengan memiliki komponen diri yang kokoh akan menolong mereka mengatasi penilaian yang menyimpang atau menyudutkan mereka yang berasal dari pihak eksternal tentang diri mereka seperti "kamu termasuk orang yang tak memiliki kemampuan atau kamu begitu bodoh, kamu tampak jelek." Dengan memiliki konsep diri yang jelas menolong mereka berdiri tegak dalam dunianya. Tidak terpengaruh oleh pandangan dunia yang berasal dari lingkungan yang menyimpang. Ciline Pricilia dkk. mengatakan kritikan dari orang lain terhadap diri para remaja dapat memengaruhi konsep diri mereka. ${ }^{22}$ Dari penegasan itu tampak kritik orang lain dapat menekan para remaja. Tetapi remaja yang sudah dewasa dalam iman akan menolong mereka mengatasinya. Artinya, ia memiliki kemampuan berkembang dan bertumbuh secara jasmani dan rohani. Penelitian ini juga mengaitkannya dengan faktor kekuatan ataupun kelemahan yang dimiliki oleh para remaja. Bagaimana seorang remaja Kristen dapat mengembangkan konsep dirinya agar sesuai dengan pandangan Allah?

Betapa pentingnya pemenuhan konsep diri bagi remaja, maka untuk memenuhinya diperlukan peran serta orang tua dan guru dalam rangka mencapai pemenuhan konsep diri tersebut. Sidjabat mengatakan bahwa guru diharapkan terpanggil bukan hanya mentransfer pengetahuan bagi para remaja tetapi juga menolong mereka bertumbuh dalam penerimaan konsep diri yang benar di dalam hidupnya, yakni menolong mereka bertumbuh dalam nilai-nilai kekekalan, bukannya hanya dipengaruhi oleh nilai kesementaraan seperti hedonisme. ${ }^{23}$ Lebih jauh John dan Susana Yates mengatakan prioritas utama orang tua adalah mendidik para remaja mengenal Tuhan. Tanggung jawab orang tua mendidik para remaja agar membiasakan mereka berjalan bersama Tuhan seperti memiliki waktu dalam firman-Nya, doa dan persekutuan pribadi dengan sesama. ${ }^{24}$ Dalam kaitan ini orang tua telah menjalankan mandat Allah dalam mendidik para remaja (Ul 6:4-9; Mat 22:37-38). Selain orang tua, guru sebenarnya juga menjadi sosok yang penting Andi, 2008).

${ }^{21}$ Binsen Samuel Sidjabat, Membesarkan Anak Dengan Kreatif, ed. Pambudi (Yogyakarta:

${ }^{22}$ Celine Pricilia, Desi Yoanita, and Daniel Budiana, "Pengaruh Bodily Shame Di Instagram Terhadap Konsep Diri Remaja Perempuan,” Jurnal E-Komunikasi 7, no. 2 (2019): 1-12.

${ }^{23}$ Sidjabat, Membesarkan Anak Dengan Kreatif.

${ }^{24}$ John Yates, Successfull Kids Through Character, ed. Wiwin (Yogyakarta: Andi, 2013). 
dalam pemenuhan konsep diri remaja. Peran guru dalam kaitan dengan mengarahkan para remaja bertumbuh ke arah yang benar. Novel Priyatna mengatakan salah satu tantangan dalam dunia remaja dipengaruhi oleh irrational beliefs di dalam hidupnya. ${ }^{25}$ Kepercayaan yang menyimpang dalam diri mereka dapat menyesatkan mereka sehingga menjauh dari Tuhan. Singgih Gunarsa melihat dari sudut krisis yang dialami oleh remaja dapat menimbulkan pengasingan diri dari lingkungan pergaulannya. ${ }^{26} \mathrm{Hal}$ itu dipengaruhi oleh sistem dunia yang direkamnya dari lingkungan pergaulan dengan teman-teman sebayanya atau lingkungan sosial di masyarakat. Tata nilai, norma dan adatistiadat yang baru dapat memengaruhi hidupnya sehingga menimbulkan krisis identitas. ${ }^{27}$ Menyimak permasalahan tersebut Priatna mengusulkan agar peran serta para pendidik dapat menolong anak didik mereka memiliki konsep diri yang benar di hadapan Allah. ${ }^{28}$ Sedangkan Ginggih Sunarsa memandang bahwa pentingnya orang tua atau guru mengidentifikasi masalah yang dihadapi remaja supaya dapat ditangani secara tepat dalam membina para remaja. ${ }^{29}$ Pergulatan para remaja tentang kehidupan mereka memang perlu direspons secara tepat oleh orang tua agar membawa mereka ke arah yang benar sesuai dengan firman Allah dan mencegah mereka jatuh ke dalam genggaman keduniawian.

Di lain pihak orang tua memiliki peran terdepan dalam pemenuhan konsep diri para remaja. Artinya tugas guru hanya pelengkap. Orang tualah yang memiliki tanggung besar dalam pemenuhan konsep diri para remaja. Tanggung jawab istimewa ini diberikan Tuhan kepada orang tua dalam membangun kepribadian anak-anak mereka. Thomas mengatakan pemenuhan aspek spiritual dalam diri anak remaja merupakan aspek yang terpenting. ${ }^{30}$ Para remaja dibina agar mengenal Allah dan mematuhi segala kehendak-Nya. mereka perlu tahu bahwa kehendak Allah bagi mereka ialah tunduk kepada-Nya serta menanggapi pekerjaan Roh-Nya di dalam hidup mereka. Itu berarti yang ditekankan bukan hanya berbuat atau melakukan sesuatu bagi Tuhan. Tunduk dan taat kepada-Nya merupakan prioritas hidup yang utama. Orang sering berbicara tentang kedewasaan rohani. Tetapi bagaimana mencapai kedewasaan rohani dalam diri para remaja. Kedewasaan rohani sebenarnya bukan tujuan yang perlu dikejar karena kedewasaan rohani merupakan aspek sampingan saja. Setiap orang termasuk para remaja tidak mungkin dapat mencapai kedewasaan rohani atas usaha sendiri atau

25 Novel Priyatna, "Peran Guru Kristen Sebagai Agen Restorasi Dan Rekonsiliasi Dalam Mengembangkan Karakter Kristus Pada Diri Remaja Sebagai Bagian Dari Proses Pengudusan," Jurnal Polyglot 13, no. 1 (2017): 1-7.

${ }^{26}$ Yulia Singgih D. Gunarsa dan Singgih D. Gunarsa, Psikologi Untuk Keluarga, ed. Nino Oktorino (Jakarta: Gunung Mulia, 2012).

${ }^{27}$ Ibid.

28 Priyatna, "Peran Guru Kristen Sebagai Agen Restorasi Dan Rekonsiliasi Dalam Mengembangkan Karakter Kristus Pada Diri Remaja Sebagai Bagian Dari Proses Pengudusan.”

${ }^{29}$ Yulia Singgih D. Gunarsa dan Singgih D. Gunarsa, Psikologi Untuk Keluarga.

30 Thomas, Sacred Parenting. 
bantuan orang lain. Kedewasaan rohani dapat dicapai melalui tunduk kepada Allah dan firman-Nya. Para pendidik juga orang tua dapat menolong anak remaja untuk tekun mempelajari firman Tuhan dan mengamalkannya dalam hidup mereka. Sejalan dengan menaati firman Allah dalam hidup mereka maka pengertian mereka tentang Tuhan dan kebenaran firman Allah juga semakin dalam dan berkembang dalam pemikiran dan tindakan mereka. Mereka semakin tenggelam dalam hubungan dan relasi dengan Tuhan, maka di situlah muncul sikap yang dewasa, pemikiran yang matang, yang mengandalkan Tuhan dan firman-Nya. Dalam konteks itu para remaja semakin menyerupai sifat Yesus. Itulah arti dan makna dari kedewasaan rohani. Kedewasan rohani bukan transfer pengetahuan atau kiat menjadi dewasa dalam iman tetapi para remaja menemukan sendiri kebenaran firman Allah yang relevan dengan hidupnya. Jadi, mengenal Allah dan hidup di dalam patokan kebenaran firman Allah menjadi fokus utama dalam pembinaan iman para remaja supaya mereka menjadi dewasa dalam Tuhan.

Thomas memandang tujuan mendidik para remaja dalam takut akan Tuhan supaya mereka mengalami perubahan dalam pemikiran secara radikal. ${ }^{31}$ Maksud dari pandangan Thomas tersebut bahwa dalam dunia ini terdapat banyak pandangan yang menyimpang yang dihadapi anak. Dengan menolong mereka dalam aspek spiritual dan iman kepada Tuhan, mereka akan mampu menampik pengaruh pemkiran keduniawian. Beliau tegaskan juga bahwa membesarkan anak yang akan mengasihi Allah dan menaati perintah-perintah-Nya. ${ }^{32}$ Para remaja Kristen dididik dalam iman karena mereka pembawa gambar Allah. Rasul Paulus mengatakan bahwa orang percaya adalah bait Roh Kudus, tempat Roh Allah mendiami hidup hidup mereka (1 Kor 6:19). Newmann mengutip prinsip firman Allah itu dan mengatakan bahwa manusia diciptakan Tuhan untuk menjadi tempat kediaman-Nya. ${ }^{33}$ Orientasi hidup orang Kristen berpusat pada aspek spiritualitas di dalam Tuhan. Tidak hanya sampai di situ para pendidik menolong para remaja memiliki pemahaman tentang hubungan dengan Allah. Tetapi mereka juga perlu memahami bagaimana karya Kristus yang telah berkurban bagi mereka sehingga memampukan mereka memiliki konsep diri yang benar. Yesus telah mati di kayu salib untuk menebus umat manusia yang berdosa termasuk para remaja (bdk. 1 Kor 15:3,4). Apa yang terjadi pada salib-Nya? Tabib Lukas menulis, "Yesus berpaling kepada mereka dan berkata: "Hai puteri-puteri Yerusalem, janganlah kamu menangisi Aku, melainkan tangisilah dirimu sendiri dan anak-anakmu" (Luk 23:28). Apa makna ayat ini? Jangan tangisi diri-Nya. Tetapi renungkan makna dibalik penderitaan-Nya. Thomas memaparkan secara gamblang makna dibalik ucapan Yesus bahwa tubuh Yesus berlumuran darah segar di seluruh bagian

\footnotetext{
${ }^{31}$ Ibid.

${ }^{32}$ Ibid.

${ }^{33}$ Connie Neumann, Pendewasaan Anak Dalam Rentang Lingkup Keluarga, ed. Nicholas Kurniawan (Bandung: Visi Press, 2009).
} 
tubuh-Nya; dari kepala hingga kaki-Nya. Tuhan telah mengurbankan seluruh jiwa raga-Nya bagi manusia (dan para remaja juga). Penampilan akhir dari hidup-Nya di kayu palang pasti kurang menarik bagi mata yang memandang. Orang pun memalingkan wajah mereka karena tak tahan melihat penderitaan-Nya yang teramat mengerikan itu. Yesus Kristus telah melakukan yang terbaik bagi manusia, juga bagi para remaja. Dia sungguh mengasihi semua orang. Dia menyelamatkan para remaja agar tidak direbut oleh keduniawian. Tuhan menyelamatkan mereka supaya memiliki masa depan bagi gereja, negara dan keluarga beriman di dunia ini. I Gusti Ayu Bintang Darmavati, Menteri Pemberdayaan Perempuan dan Perlindungan Anak mengatakan seperti yang dikutip oleh Zubi Mahrofi kantor berita AntaraNews.com (2/5/2021) bahwa anak remaja merupakan investasi penting bagi negara. ${ }^{34}$ Penegasan ini memang sesuai dengan kenyataan bahwa negara membutuhkan generasi muda bagi pembangunan bangsa dan negara. Demikian juga gereja membutuhkan mereka sebagai penerus kaum beriman. Itulah tujuan utama dalam membina iman para remaja supaya mereka tahu dan mengenali bahwa Yesus Kristus yang telah mengasihi dan menyelamatkan mereka dari hukuman dosa dan maut supaya mereka dapat menyumbang pemikiran atau kreativitas atau rela berkurban bagi kemajuan umat Allah di tempat mereka mengabdi.

Dupe mengatakan bahwa konsep diri yang benar hanya dapat ditemukan dalam Yesus Kristus. ${ }^{35}$ Tidak ada kiat jitu untuk mencapai konsep diri yang benar selain mereka hidup dan bertekun di dalam kebenaran firman Allah. Atau dengan kata lain mereka memiliki kerinduan untuk bertaat kepada firman-Nya. Jika mereka bergaul dengan Yesus Kristus dan menaati firman-Nya, maka mereka akan mengalami kuasa kuasa Allah yang bekerja di dalam diri mereka sehingga membentuk hidup mereka menjadi serupa dengan Yesus Kristus. Dupe mengatakan para remaja yang memiliki konsep diri yang benar dapat dilihat dari cara hidup mereka yang mengikuti cara hidup hidup dan ajaran Yesus. ${ }^{36}$ Mereka dibentuk untuk menjadi serupa dengan sifat-sifat Yesus. Yakni mereka memiliki sikap yang dengar-dengaran akan firman Allah dan taat pada kehendak-Nya di dalam hidup mereka. Setidaknya tampak buah Roh yang bekerja secara nyata dalam hidup mereka dengan mengekspresikan moralitas Kristen yang utuh.

Orang tua tidak hanya memberi arah bagi para remaja mereka tetapi juga diperlukan tindakan yang praktis. Slayton mengutarakan cara beliau menolong anak remajanya berkembang dalam pemahaman tentang kemajuan diri mereka. Dia menolong anak remajanya bertumbuh dalam hal knowledge dengan memberi

34 Zubi Mahrofi, 'Mentri PPPA: Anak-Anak Investasi Penting Negara', AntaraNews.Com (Jakarta, 2021), 1.

35 Selvy Iriany Susanti Dupe, "Konsep Diri Remaja Kristen Dalam Menghadapi Perubahan Zaman," Jurnal Ilmiah Religiosity Entity Humanity (JIREH) 2, no. 1 (2020): 53-69.

${ }^{36}$ Ibid. 
mereka buku untuk dipelajari dan didiskusikan bersama dengan mereka. ${ }^{37}$ Dalam hal ini bacaan yang membantu pemahaman dan wawasan mereka tentang dunia remaja dan bagaimana bertumbuh secara sehat dan benar. Juga berarti membentuk konsep diri mereka. Tidak hanya sampai di situ, Slayton, malah mengusulkan agar orang tua perlu memantau para remaja mereka secara jarak jauh dengan mengirim surat pesan singkat secara elektronik atau email yang terfokus pada kehidupan mereka, menanyakan keadaan mereka atau bagaimana dengan kemajuan semester yang berjalan atau tentang pertemanan mereka atau tentang guru sains yang baru. ${ }^{38}$ Pandangan dan masukan yang diajukan Slayton terlihat seperti hal yang biasa-biasa saja tetapi sebenarnya di dalam komunikasi semacam ini termuat makna tentang membangun relasi yang sehat dengan para remaja bahwa mereka tidak dibiarkan berjalan sendiri dalam menapaki dunia remaja yang tengah dijalani mereka. Kesannya bahwa mereka begitu penting di hadapan orang tua. Setiap kesempatan dapat dipakai oleh orang tua untuk terusmenerus membina hubungan yang sehat dengan anak-anak mereka. Saputri dan Moordiningsih memaparkan bahwa konsep diri remaja dapat terbentuk melalui hubungan yang dekat dengan orang tuanya. Keterjalinan komunikasi yang sehat dalam keluarga turut membangun konsep diri remaja. ${ }^{39}$ Lebih lanjut keduanya mengatakan bahwa dukungan keluarga bagi pembentukan konsep diri begitu penting bagi para remaja. Bentuk-bentuk itu berupa memberi perhatian, memotivasi dan menasihati mereka sesuai dengan kebutuhan mereka. ${ }^{40} \mathrm{Di}$ sini menyangkut arahan dari orang tua untuk membangun hidup anak mereka menjadi anak yang taat dan mengikuti jalan yang benar sesuai firman Allah.

Wening memaparkan bahwa ketaatan dalam membaca kitab suci dan literatur rohani untuk membangun dimensi religiositas para remaja. ${ }^{41}$ Selain diarahkan dari luar tetapi mereka juga memiliki kerinduan yang dalam untuk mencari kebenaran demi pertumbuhan rohani mereka. Dalam pemahaman Wening peran orang tua begitu penting dalam membangun konsep diri remaja yang ditunjang dengan teladan, disiplin, komunikasi dan penerimaan terhadap remaja. ${ }^{42}$ Tanpa bantuan orang tua anak remaja akan merasa berjalan sendiri dan itu bisa membuat mereka mandek tetapi karena ayah dan ibu mereka menolong aspek kerohanian mereka maka mereka juga terbentuk model yang mencari sumber kekuatan dari Tuhan. Dupe juga melihat bahwa para remaja dapat bertumbuh dalam konsep diri yang sehat melalui peran serta orang tua dalam membangun

${ }^{37}$ Gregory Slayton, Be a Better Dad Today (Jakarta: Asosiasi Gereja-gereja Thionghoa, 2007).

${ }^{38}$ Ibid.

39 Marliana Eka Saputri; Moordiningsih, "Pembentukan Konsep Diri Remaja Pada Keluarga Jawa Yang Beragama Islam,” Jurnal Ilmiah Psikologi Terapan 4, no. 2 (2016): 261-268.

${ }^{40}$ Ibid.

${ }^{41}$ Wening, "Pengaruh Pola Asuh Autoritatif Terhadap Religiositas Remaja Gereja Kristen Jawa Se-Klasis Surakarta."

${ }^{42}$ Ibid. 
hidup mereka melalui komunikasi yang intens untuk mengatasi permasalahan yang mungkin terjadi di dalam pertumbuhan mereka. ${ }^{43}$ Tidak dapat dipungkiri bahwa keluarga sebagai arena pembelajaran yang strategis bagi para remaja dalam mengembangkan diri mereka semakin maju dan bertumbuh menjadi serupa dengan Yesus Kristus. Hubungan yang harmonis dengan Tuhan menjadi faktor penentu terbentuknya komponen konsep diri yang sehat dan benar bagi para remaja. Tidak ada seorang tokoh pun dalam dunia yang sanggup memenuhi konsep diri manusia. Konsep diri bagi orang Kristen hanya dipenuhi oleh Yesus.

\section{Dunia Menantang dan Menjebak Mereka}

Realitasnya para remaja tumbuh kembang dalam dunia yang menawarkan tawaran yang menggoda seperti menjadi orang yang diperhitungkan. Anak-anak Zebedeus yakni Yakobus dan Yohanes terjerat dalam ketegori ini. Ibu mereka memohon kepada Yesus supaya kedua anaknya diberi kedudukan penting di dalam Kerajaan Allah (Mat 20:20-24; Mrk 10:35-41). Dalam Bible Works 10 kata kedudukan digunakan kata $\kappa \alpha \theta i ́ \sigma \omega \sigma \iota v$ verb subjunctive aorist active 3rd person plural from $\kappa \alpha \theta i \zeta \omega$ yang dapat diterjemahkan meminta kedudukan atau mendapat posisi atau turut mengatur yang secara kiasan berarti ikut memimpin. Di sini sang Ibu ambisius ini meminta agar anak-anaknya berkuasa juga di dalam Kerajaan Allah. Suatu permintaan yang terlalu naif, juga bodoh. Namun, Yesus mengoreksi sikap ini dengan mengatakan masalah kedudukan di dalam Kerajaan telah disediakan bagi mereka yang berhak dan hal ini merupakan wewenang Sang Bapa, bukan diri-Nya. Itu berarti di hadapan Tuhan tidak ada kompetisi untuk untuk menjadi orang terkemuka. Orang percaya dianjurkan untuk berlomba agar mencapai garis finish dalam iman dan ketaatan kepada Tuhan. Mencapai garis akhir bukan bukan untuk menjadi orang terkemuka atau terhebat. Permohonan Ibunda dari anak-anak Zabedeus itu ditolak olehYesus. Karena permohonan tersebut egois dan di luar kehendak Tuhan. Maka penulis setuju dengan penelitian Alvin Jeremiah yang mengatakan bahwa permintaan Ibu dari Yakobus dan Yohanes tidak mencerminkan sikap kehambaan yang telah ditunjukkan Yesus kepada orang banyak terutama kepada para rasul-Nya. ${ }^{44}$ Itu berarti sikap kehambaan dalam melayani lebih penting daripada mengharapkan kedudukan atau posisi terhormat.

Jika orang tua mulai mendeteksi adanya unsur-unsur konsep diri yang keliru merambah dalam diri anak remaja, maka hal itu sebagai suatu pertanda yang baik untuk mulai bertindak dan mengambil langkah untuk membimbing dan membenahi konsep diri anak menuju arah yang sehat di hadapan Allah. Dalam membentuk konsep diri anak, orang tua sedang berhadapan dengan peperangan

\footnotetext{
${ }^{43}$ Dupe, "Konsep Diri Remaja Kristen Dalam Menghadapi Perubahan Zaman."

44 Bandingkan kajian Alvin Jeremiah, "KEMURAHAN TERHADAP PEKERJA RUMAH TANGGA : PRAKTIK SPIRITUAL BAGI PARA MAJIKAN” 1, no. April (2013): 40.
} 
rohani, yakni bagaimana memenangkan hati anak mereka untuk tunduk pada wewenang Allah sebagaimana dituntut dalam Alkitab. Heath menegaskan bahwa tanggung jawab utama orang tua dalam keluarga berkaitan dengan pembinaan iman dan kerohanian anak. ${ }^{45}$ Anak dididik dalam iman agar memiliki tata nilai yang sesuai dengan hukum Allah. Thomas menegaskan secara tepat bahwa membina anak merupakan tugas yang kompleks dan memerlukan ketekunan orang tua untuk membesarkan mereka dalam iman. ${ }^{46}$ Pembentukan konsep diri remaja yang kompleks itu memerlukan penanganan dengan kasih sayang dari orang tua. Ade Wulandari mengatakan tempat yang tepat dalam pembentukan konsep diri remaja adalah orang tua mereka. ${ }^{47}$ Keberadaan mereka dalam genggaman orang tua merupakan awal dari pembentukan konsep diri mereka. Hal ini sebagai peluang dan kesempatan emas bagi orang tua memenuhi moralitas dan kebenaran firman Allah dalam diri buah hati mereka.

Orang tua perlu menegaskan juga bahwa dalam dunia ini orang lebih giat mencari ketenaran, materi dan prestasi ketimbang Tuhan. Hal itu sudah ditentang oleh Amsal Salomo 6:6-19. Tuhan membenci kecenderungan hati manusia berlaku angkuh di hadapan Tuhan. Yakobus juga menolak kosep dunia itu (Yak 4:6). Alkitab justru menuntut kerendahan hati yang berpusat pada Tuhan Yesus Kristus (Flp 2:1-11). Konsep diri tampaknya tidak berkaitan dengan berprestasi, juga kemapanan hidup, tetapi berkaitan dengan watak dan tata nilai Kristen yang menjadi serupa dengan Yesus Kristus.

\section{Apa yang Terjadi di dalam Diriku?}

Dadan Sumara dkk. mengatakan bahwa krisis identitas sering melanda para remaja. Secara internal, mereka berhadapan dengan krisis. ${ }^{48}$ Dalam realitasnya, anak remaja suka bertanya tentang siapa dirinya. Apalagi kalau bentuk tubuh mereka mulai berubah. Mereka gelisah seiring dengah perubuhan fisiknya. Anak perempuan suka mengeluh karena pinggulnya berubah bentuk atau payudaranya mulai membentuk. Anak laki-kali agak kagok dengan suara mereka, berkumis halus dan seperti tiba-tiba ia lebih tinggi dari temannya. Apalagi pada waktu mereka mengalami mimpi basah. Jerawat yang tumbuh pada wajah mereka pun bisa jadi masalah yang dipikirkan berhari-hari. Hal-hal ini bisa mengganggu emosi dan cara pandang terhadap diri mereka. Untuk itu dalam tahap ini kepekaan orang tua dibutuhkan. Setidakya orang tua dapat mengambil langkah praktis untuk mengarahkan mereka bahwa perubahan fisik sebagai bagian yang alamiah bagi seorang remaja yang bertumbuh menjadi dewasa. Hal ini penting untuk meredam

\footnotetext{
${ }^{45}$ Heath, Teologi Pendidikan Anak.

46 Thomas, Sacred Parenting.

47 Ade Wulandari, "Karakteristik Pertumbuhan Perkembangan Remaja Dan Implikasinya Terhadap Masalah Kesehatan Dan Keperawatannya," Jurnal Keperawatan Anak 2 (2014): 39-43.

${ }^{48}$ D; Sumara, S; Humaedi, and M. D Santoso, "Kenalakan Remaja Dan Penanganannya," penelitian \& PPM 4, no. kenkalan remaja (2017): 129-389.
} 
emosi negatif tidak berlarut-larut dalam benak mereka. Mereka perlu memahami diri mereka di hadapan Tuhan itu jauh lebih utama, bukan sekadar memikirkan diri sendiri. Mereka tidak patut membandingkan diri mereka dengan orang lain. Julianto Simanjuntak mengusulkan agar orang tua dapat membimbing para remaja mereka dengan sikap kasih, penuh pengertian, kesabaran dan suasana akrab dengan para remaja agar terbentuk harga diri secara benar dan menolong mereka menerima dirinya serta tidak dihantui dengan perasaan negatif. 49

Untuk itu kehadiran orang tua begitu penting untuk menopang pertumbuhan anak remaja mereka. Orang tua seyogianya membuka matanya terhadap konflik anak remaja dengan dirinya. Sidjabat memandang peran orang tua perlu diaktifkan ketika anak sudah menanjak remaja. ${ }^{50}$ Para remaja yang tengah bergelut dengan berbagi konflik dalam diri mereka dapat diatasi dengan bantuan bimbingan dan arahan dari orang tua. Sidjabat menambahkan bahwa dalam menghadapi masa transisi, para remaja tidak patut dibiarkan berjalan sendiri. Orang tua atau guru perlu mendampingi mereka agar mereka mampu keluar dari krisis atau konflik yang dialami mereka. ${ }^{51}$ Dupe melihat betapa pentingnya dialog atau hubungan yang akrab dengan para remaja dalam membangun konsep diri mereka sehingga mereka mampu mengatasi kekalutan dalam diri mereka. ${ }^{52}$ Dialog timbal-balik antara orang tua dengan anak akan menolong tercipta suasana yang akrab demi mencapai tujuan pembentukan konsep diri para remana. Orang tua berinisiatif menata hidup anaknya dan sebaliknya anak juga terbuka untuk merespons masukan arahan dari orangtunya. Ratu Pa juga melihat peran keluarga begitu penting dalam pembentukan konsep diri remaja karena orang tua dapat membangun kepercayaan diri remaja. ${ }^{53}$ Arena keluarga sebagai wadah strategi membangun hidup anak-anak mereka. Mau tidak mau, keluarga patut mengisi ruang konsep diri secara tepat bagi masa depan para remaja karena orang tua memiliki kesempatan yang luas untuk mengarahkan arah hidup mereka berpusat kepada Kristus. ${ }^{54}$ Lebih jauh $\mathrm{Pa}$ menegaskan bahwa keluarga menempati urutan terdepan dalam pembentukan konsep diri remaja. ${ }^{55}$ Jelas sekali bahwa para remaja membutuhkan peran aktif orang tua dalam membina iman mereka. Mengingat bahwa mereka senantiasa bertumbuh. Semua perubahan-perubahan psikis dan fisik itu terjadi seiring mereka menanjak dewasa. Orang yang bertumbuh seyogianya selalu siap menghadapi perubahan. Inilah

${ }^{49}$ Julianto Simanjuntak and Roswitha Ndraha, Mendidik Anak Sesuai Zaman \& Kemampuannya (Jakarta: LK3, 2007), 139-144.

${ }^{50}$ Sidjabat, Membesarkan Anak Dengan Kreatif.

51 Ibid.

52 Dupe, "Konsep Diri Remaja Kristen Dalam Menghadapi Perubahan Zaman."

53 Jubliana Anthoneta Ratu Pa, "Kepercayaan Diri Remaja," Sanctum Domine: Jurnal Teologi 4, no. 1 (2019): 54-76. ${ }^{54}$ Nggebu, Desain Allah Bagi Anak Dan Remaja: Membesarkan Anak Semakin Mendewasakan
Orangtua.

${ }^{55} \mathrm{~Pa}$, "Kepercayaan Diri Remaja." 
tantangan yang rawan dan rapuh bagi para remaja.

Singgih memaparkan bahwa secara psikis mereka merasa canggung, gelisah, murung dan kikuk terhadap diri sendiri. ${ }^{56}$ Mereka sering memberontak dengan dirinya sendiri atau melanggar tata krama atau menolak otoritas yang ada. Ia mempertanyakan perubahan bahkan menolaknya. Situasi ini harus diatasi dengan bimbingan yang benar dan tepat sesuai firman Allah. Mereka patut ditolong untuk menerima dirinya dengan sukacita dan rasa syukur kepada Allah. Itulah tugas besar bagi orang tua dalam berperan aktif menata kepribadian para remaja supaya mereka memiliki cara pandang yang sehati terhadap dirinya sendiri.

\section{Komponen Konsep Diri Remaja}

Komponen konsep diri remaja dapat dilihat dari dua aspek. (1). Segi kognitif. Arti kata ini berkaitan dengan pemahaman tentang diri sendiri yang berkaitan dengan hal-hal yang bersifat aktual. Mungkin para remaja sedang berpikir bahwa diri mereka tidak sepandai temannya. Ini sebagai krisis dalam memandang diri sendiri. Wright menggambarkan orang yang meragukan tentang dirinya sendiri karena melihat dirinya sesuai dengan gambarannya. ${ }^{57}$ Dengan kata lain mereka berasosiasi bahwa diri mereka tergolong orang yang bodoh. Minder dan kurang percaya diri. Sebaliknya jika seorang remaja menadang dirinya secara benar dan bersyukur dengan apa yang dimilikinya maka ia memiliki kesempatan mengembangkan kemampuannya untuk melangkah lebih maju. Sebab Tuhan tahu aktivitas berpikiran manusia (Mat 12:25; Luk 11:17). Para remaja diharapkan memiliki kerinduan memikirkan tentang kehendak Tuhan (Flp 2:1-11). Bahkan rasul Paulus mengatakan bahwa firman Allah berkuasa mengubahkan manusia (pikiran para remaja) agar selaras dengan kehendak Allah (bdk. Rm 12:1-2).

(2) Segi afektif. Arti istilah afektif dikaitkan dengan perasaan secara batiniah yang sering menguasi para remaja. Mereka yang sudah memahami konsep diri mereka secara jelas akan menunjukkan kepribadian yang tenang, riang dan gembira. Akan tetapi jika yang terjadi sebaliknya maka diri mereka dihantui oleh perasaan gelisah, murung dan khawatir tentang masa depannya. Mereka juga merasa kurang puas dengan dirinya. Mengeluh tentang keadaan ekonomi keluarga yang pas-pasan. Bagian ini dapat disebut krisis secara perasaan tentang dirinya. Psikiater William Gaylin, memaparkan bahwa orang yang sering menggambarkan dirinya buruk akan membentuk kebiasaannya pada dirinya seperti itu. ${ }^{58}$ Pemahaman yang keliru yang dikenakan pada diri sendiri, lama-kelamaan hal itu membentuk pandangan dunia yang permanen terhadap dirinya sendiri dan tentu saja sangat merugikannya. Di balik semuanya ini yang terjadi adalah ada oknum

\footnotetext{
${ }^{56}$ Yulia Singgih D. Gunarsa dan Singgih D. Gunarsa, Psikologi Untuk Keluarga.

${ }^{57}$ Norman Wright, Self Image (New York: Harvest House Pub, 1983).

${ }^{58}$ William Backus, Mengapa Aku Merasa Begini? (Semarang: Bethany, 1992).
} 
lain yang mengambil peranan penting. Itulah kerja Iblis. Si Pendusta sebenarnya sedang menanamkan ide-ide yang buruk itu dalam pikiran dan hati anak-anak remaja supaya hidup mereka menjauhkan dari otoritas Tuhan dan hanya takluk pada kekuasaan keduniawian.

Dengan demikian kebutuhan yang penting bagi golongan remaja seperti ini ialah memantapkan identitas mereka di hadapan Allah. Orang percaya memiliki saluran yang terbuka lebar untuk berkomunikasi dengan Yesus. Keluh-kesah mereka dapat disampaikan kepada-Nya. Yesus digambarkan sebagai Sang Gembala yang mengenal setiap suara domba milik-Nya (bdk. Yoh 10:3); itu berarti Dia tahu permasalahan para remaja satu per satu. Tuhan berdaulat dalam menjamin kebutuhan para remaja yang beriman kepada-Nya (bdk. Yoh 10:10). Bahkan Yesus menuntut agar mereka tidak gelisah tetapi percaya kepada-Nya (bdk. Yoh 14:120). Secara alkitabiah para remaja Kristen yang menerima konsep dirinya secara sehat berarti ia bersandar kepada Kristus yang berkuasa memelihara dirinya.

Berdasarkan pembahasan tersebut di atas, Sidjabat mengatakan kehadiran para remaja dalam keluarga agar orang tua mereka berperan aktif membina iman mereka. ${ }^{59}$ Keluarga menjadi sentral pembinaan iman agar para remaja memiliki pengharapan dan bersandar penuh pada pimpinan Tuhan. Selain itu, Alouw mengungkapkan tentang orang yang telah bertumbuh dalam Yesus akan memiliki pikiran dan perasaan/kemauan yang diperlihatkan melalui tingkah laku yang alkitabiah. ${ }^{60}$ Itu berarti krisis konsep diri pada para remaja dapat dipenuhi dalam Yesus Kristus melalui pembinaan iman dalam keluarga. Di sinilah letak pentingnya tugas eksklusif orang tua dalam mengayomi dan memantapkan iman para remajanya.

\section{Menata Konsep Diri yang Sehat bagi Para Remaja Kristen}

Orang Kristen perlu mencermati Khotbah Di Bukit (Mat 5-7); di situ tampak sekali Tuhan Yesus menentang agar apa yang dikejar dunia. Sebaliknya didiklah mereka agar memiliki watak dan karakter serta kerendahan hati di dalam Yesus Kristus; menjadi prioritas utama yang seyogianya dibangun dan ditata dalam diri para remaja Kristen. Karena jika seorang remaja memiliki buah Roh dalam hidupnya maka itulah kekuatan utama baginya untuk berjuang dan memenuhi masa depannya bersama dengan Tuhan Yesus Kristus. Anak dan para remaja didewasakan dalam keluarga supaya mereka merekam pola pembinaan iman yang menjadi gaya hidup mereka karena orang tua merupakan sumber peragaan

\footnotetext{
${ }^{59}$ Sidjabat, Membesarkan Anak Dengan Kreatif.

${ }^{60}$ Bandingkan Rudy A. Alouw, Teori Dan Prinsip Konseling Kristen, ed. Faisal and Welhelmina K. Mattulesy (Bandung: Kalam Hidup, 2014), 65-70.
} 
teladan dalam kerohanian. ${ }^{61}$

Secara alkitabiah masalah konsep diri bukan diperoleh melalui kesuksesan yang dicapai secara menusiawi atau berusaha dengan kemampuan sendiri. Pandangan seperti itu bukanlah kehendak Yesus. Konsep diri yang benar mesti dibangun di atas dasar iman kepada-Nya. Hidup yang beriman dapat diartikan sebagai gaya hidup yang menyerahkan total segala keberadaan diri kepada Yesus. Melalui gaya hidup yang mengutamakan kehendak Allah, senantiasa bersyukur atas pimpinan-Nya dan menerima diri sebagaimana Allah mendesain setiap orang secara unik di hadapan-Nya. Dengan kata lain konsep diri sebagai Anak Allah (Yoh 1:12) merupakan pokok utama bagi para remaja Kristen. Cara pandang seperti ini akan membuat diri para remaja menjadi sosok yang kokoh dan tak mudah digoyahkan oleh "arus dunia ini."

Alkitab mengatakan bahwa Tuhan Yesus telah mati dan bangkit untuk manusia supaya harga diri mereka dipenuhi oleh kasih-Nya (Yoh 3:16; 1Kor 15:34). Dengan demikian harga diri para remaja Kristen telah dibayar lunas oleh Tuhan Yesus di kayu salib. Itulah kasih yang terbesar (1Kor 13:13) dari Allah yang kekal bagi mereka. Karena itu, para remaja Kristen dapat menjadi pribadi pemenang atas segala godaan dalam dunia ini. Mereka diharapkan tidak terjebak dengan tawaran dunia. Mereka senantiasa fokus untuk menaati firman Allah. Orang yang mengasihi Tuhan dimampukan untuk mengatakan "NO" terhadap dunia ini, dan senantiasa terngiang "YES" kepada suara Tuhan. Mereka menjadi pemenang karena Yesus Kristus telah berkurban untuk mereka dan memenuhi hati mereka dengan kasih Allah. Siapa yang dapat memisahkan para remaja Kristen yang telah ditebus dalam Kristus? (bdk. Rm 8:28). Jawaban tidak! Mereka aman dalam perlindungan Yesus Kristus.

Setiap remaja Kristen memiliki pribadi unik karena setiap orang diciptakan tidak persis sama dengan orang lain. Serupa tetapi tidak sama. Mereka sapatutnya menjadi diri mereka sendiri. Kalau mereka mau menjadi sama dengan orang lain berarti mereka sedang tertipu. Tipuan itu dapat membahayakan dan menghancurkan masa depan para remaja Kristen. Maka pada sisi inilah peran orang tua membimbing para remaja untuk mengalami buah Roh dalam hidup mereka (Gal 5:22-23) merupakan panggilan yang mendesak dan urgent. Kondisi itu memungkinkan mereka hidup dalam anugerah-Nya. Karena itu, yang menjadi fokus perhatian orang tua di zaman modern ini adalah mendidik para remaja Kristen agar berjalan pada jalan yang benar dan memohon pertolongan Yesus Kristus untuk memenuhi hati mereka dengan sifat dan buah Roh, sikap yang rendah hati serta senantiasa bersandar kepada-Nya. Pengurbanan orang tua dalam

\footnotetext{
${ }^{61}$ Bandingkan uraian Sostenis Nggebu, "Pemuridan Model Epafras Sebagai Upaya Pendewasaan Iman Kristen The Model of Epaphras Discipleship as an Effort of Maturing of Church Members Faith," Pengarah: Jurnal Teologi Kristen 3, no. 1 (2021): 38.
} 
membimbing para remaha sering disertai dengan pengurbanan yang setulustulusnya, tanpa pamrih. ${ }^{62}$ Itu berarti keberadaan mereka di hadapan-Nya sangatlah unik dan penting. Mereka dikasihi Allah; diselamatkan Yesus Kristus; disucikan dari dosa; dijadikan milik kepunyaan Allah; Roh Allah mendiami hati mereka. Ini menjadi kebenaran tentang kasih karunia Allah bagi para remaja Kristen, yang membuat hidup mereka aman dan terlindungi di dalam Yesus Kristus, serta mampu mengekspresikan diri mereka sebagai pribadi yang tangguh dalam era global ini dan bahkan tidak mudah dikalahkan oleh arus dunia ini.

\section{KESIMPULAN}

Secara personal setiap orang tua dipanggil Allah untuk membentuk konsep diri para remajanya. Untuk mencapai tujuan itu, Allah memperlengkapi setiap orang tua dengan otoritas-Nya dan dalam pimpinan Roh Kudus. Para remaja Kristen patut dibimbing dalam terang firman Allah supaya berpikir, berjalan dan bertingkah laku sesuai citra Yesus Kristus. Mereka diperlengkapi dalam firman Allah karena mereka milik kepunyaan Allah, menjadi warga Kerajaan Allah, dan bukan milik dunia atau milik suatu kemargaan. Itulah sebabnya keluarga inti sebagai tempat pertama dan terutama bagi pemenuhan komponen konsep diri para remaja agar menjadi orang yang dewasa dalam iman. Di sanalah orang tua mendewasakan mereka dengan menciptakan suasana yang nyaman dan teraman untuk menanamkan nilai moralitas bagi para remaja. Itu artinya, tiada tujuan yang lain, bahwa kehadiran para remaja dalam keluarga supaya orang tua memengaruhi mereka hidup susuai kebenaran firman Allah di era global masa kini. Tentu saja bahwa peran eksklusif ini tak dapat tergantikan oleh orang lain karena tugas guru atau mentor rohani hanyalah sebagai pelengkap dalam pembinaan dan memperlengkapi secara rohani bagi para remaja Kristen. Orangtua.

${ }^{62}$ Nggebu, Desain Allah Bagi Anak Dan Remaja: Membesarkan Anak Semakin Mendewasakan 


\section{DAFTAR PUSTAKA}

Alouw, Rudy A. Teori Dan Prinsip Konseling Kristen. Edited by Faisal and Welhelmina K. Mattulesy. Bandung: Kalam Hidup, 2014.

Arikunto, Suharsimi. Prosedur Penelitian. Jakarta: Rineka Cipta, 2013.

Backus, William. Mengapa Aku Merasa Begini? Semarang: Bethany, 1992.

Darmawan, I Putu Ayub. "Pembelajaran Memorisasi Dalam Ulangan 6:6-9." EPIGRAPHE: Jurnal Teologi dan Pelayanan Kristiani 3, no. 1 (2019): 21.

Dongoran, Darminto, and Fredik Melkias Boiliu. "Pergaulan Teman Sebaya Dalam Pembentukan Konsep Diri Siswa." Jurnal Educatio FKIP Unma 6, no. 2 (2020): 381-388.

Dupe, Selvy Iriany Susanti. "Konsep Diri Remaja Kristen Dalam Menghadapi Perubahan Zaman." Jurnal Ilmiah Religiosity Entity Humanity (JIREH) 2, no. 1 (2020): 53-69.

Galugu, Nur Saqinah, and Samsinar. "Academic Self-Concept, Teacher's Supports and Student's Engagement in the School." Jurnal Psikologi Pendidikan dan Konseling: Jurnal Kajian Psikologi Pendidikan dan Bimbingan Konseling 5, no. 2 (2019): 141.

Hamdi, Mohamad. Teori Kepribadian, Jilid 2. Bandung: Alfabeta, 2016.

Heath, W.S. Teologi Pendidikan Anak. Edited by Yosep Kurnia. Bandung: Kalam Hidup, 2005.

Hensley, Margaret. Konsep Diri Dan Kedewasaan Rohani. Bandung: Kalam Hidup, 1993.

Jeremiah, Alvin. "KEMURAHAN TERHADAP PEKERJA RUMAH TANGGA : PRAKTIK SPIRITUAL BAGI PARA MAJIKAN” 1, no. April (2013): 37-52.

Liana Asnita dkk. "HUBUNGAN TINGKAT STRES DENGAN HARGA DIRI REMAJA DI LEMBAGA PEMASYARAKATAN.” Jurnal JOM Program Studi Keperawatan Universitas Riau 2, no. 2 (2015).

Mahrofi, Zubi. "Mentri PPPA: Anak-Anak Investasi Penting Negara." AntaraNews.Com. Jakarta, 2021.

Manurung, Kosma. "Studi Analisis Pandangan Nabi Terhadap Nubuat Palsu." Jurnal Antusias 6, no. 6 (2020).

Marliana Eka Saputri; Moordiningsih. "Pembentukan Konsep Diri Remaja Pada Keluarga Jawa Yang Beragama Islam.” Jurnal Ilmiah Psikologi Terapan 4, no. 2 (2016): 261-268.

Mary, Eirene. "Implikasi Ulangan 5:16 Dalam Pendidikan Keluarga." Didache: Journal of Christian Education 1, no. 2 (2020): 141.

Mazya, Kharisma Nail, and Ratna Supradewi. "Konsep Diri Dan Kebermaknaan Hidup Pada Remaja Di Panti Asuhan.” Proyeksi; Jurnal Psikologi, Unissula 6, no. 2 (2021).

Nainupu, Astrid Maryam Yvonny, and Ayang Emiyati. "Kunci Keberhasilan Seorang Anak Dalam Pemaparan Alkitab." Didache: Journal of Christian Education 1, no. 2 (2020): 91.

Neumann, Connie. Pendewasaan Anak Dalam Rentang Lingkup Keluarga. Edited by Nicholas Kurniawan. Bandung: Visi Press, 2009.

Nggebu, Sostenis. Desain Allah Bagi Anak Dan Remaja: Membesarkan Anak Semakin Mendewasakan Orangtua. Edited by Heru Winoto. Bandung: Biji Sesawi, 2016.

___. "Pemuridan Model Epafras Sebagai Upaya Pendewasaan Iman Kristen The 
Model of Epaphras Discipleship as an Effort of Maturing of Church Members

Faith." Pengarah: Jurnal Teologi Kristen 3, no. 1 (2021): 26-42.

$\mathrm{Pa}$, Jubliana Anthoneta Ratu. "Kepercayaan Diri Remaja." Sanctum Domine: Jurnal Teologi 4, no. 1 (2019): 54-76.

Pricilia, Celine, Desi Yoanita, and Daniel Budiana. "Pengaruh Bodily Shame Di Instagram Terhadap Konsep Diri Remaja Perempuan." Jurnal E-Komunikasi 7, no. 2 (2019): 1-12.

Priyatna, Novel. "Peran Guru Kristen Sebagai Agen Restorasi Dan Rekonsiliasi Dalam Mengembangkan Karakter Kristus Pada Diri Remaja Sebagai Bagian Dari Proses Pengudusan." Jurnal Polyglot 13, no. 1 (2017): 1-7.

Putra, Adi. "Monarki: Penolakan Terhadap Teokrasi." Explore Contact FAQ (2021). Rikayanti, Anisah, and Muhammad Nur. "Hubungan Harga Diri Dengan Aktualisasi Diri Pada Remaja Putri Dengan Obisitas Di SMA Negeri 4 Makassar." Jurnal Stikes Nani Hasanuddin 3, no. 6 (2013): 99-104.

Sidjabat, Binsen Samuel. Membesarkan Anak Dengan Kreatif. Edited by Pambudi. Yogyakarta: Andi, 2008.

Simanjuntak, Julianto, and Roswitha Ndraha. Mendidik Anak Sesuai Zaman \& Kemampuannya. Jakarta: LK3, 2007.

Slayton, Gregory. Be a Better Dad Today. Jakarta: Asosiasi Gereja-gereja Thionghoa, 2007.

Soesilo, Yushak. "Keluarga Eli Dalam 1 Samuel 2:11-36: Suatu Evaluasi Pendidikan Kristen Dalam Keluarga Hamba Tuhan.” Jurnal Antusias 3, no. 5 (2014): 136146.

Sumara, D; S; Humaedi, and M. D Santoso. "Kenalakan Remaja Dan Penanganannya." penelitian \& PPM 4, no. kenkalan remaja (2017): 129-389.

Thomas, Gary. Sacred Parenting. Edited by Ellen Hanafi. Yogyakarta: Gloria, 2015.

Wening, Sri. "Pengaruh Pola Asuh Autoritatif Terhadap Religiositas Remaja Gereja Kristen Jawa Se-Klasis Surakarta." Kurios 4, no. 1 (2018): 74.

Wright, Norman. Self Image. New York: Harvest House Pub, 1983.

Wulandari, Ade. "Karakteristik Pertumbuhan Perkembangan Remaja Dan Implikasinya Terhadap Masalah Kesehatan Dan Keperawatannya." Jurnal Keperawatan Anak 2 (2014): 39-43.

Yates, John. Successfull Kids Through Character. Edited by Wiwin. Yogyakarta: Andi, 2013.

Yulia Singgih D. Gunarsa dan Singgih D. Gunarsa. Psikologi Untuk Keluarga. Edited by Nino Oktorino. Jakarta: Gunung Mulia, 2012.

\section{Software Komputer:}

Bible Works 10 versi 10.0.4.114 (Starup 8.88 secs) 